medRxiv preprint doi: https://doi.org/10.1101/2021.07.06.21259749; this version posted July 18, 2021. The copyright holder for this preprint (which was not certified by peer review) is the author/funder, who has granted medRxiv a license to display the preprint in perpetuity. It is made available under a CC-BY-NC 4.0 International license .

\title{
Application of nasal spray containing dimethyl sulfoxide (DMSO) and ethanol during the COVID-19 pandemic may protect healthcare workers: A randomized controlled trials
}

Ali Hosseinzadeh ${ }^{1}$, Abbas Tavakoliann2, Vahid Kia ${ }^{3}$, Hossein Ebrahimi ${ }^{4}$, Hossein Sheibani ${ }^{5}$, Ehsan Binesh ${ }^{5}$, Reza Jafari $_{2}{ }_{2}$ Seyed Mohammad Mirrezaie ${ }^{6}$, Moslem Jafarisani ${ }^{7}$, Mohammad Hassan Emamian ${ }^{1}$

1: Epidemiology Department, Health School. Shahroud University School of Medical Sciences, Shahroud, Iran.

2: Islamic Azad University, Shahroud Branch, Shahroud, Iran.

3: School of Medicine, Shahroud University School of Medical Sciences, Shahroud, Iran.

4: School of Nursing and Midwifery, Shahroud University School of Medical Sciences, Shahroud, Iran.

5: Clinical Research Development Unit, Imam Hossein Hospital, Shahroud University of Medical Sciences, Shahroud, Iran

6: Center for Health Related Social and Behavioral Sciences Research, Shahroud University of Medical Sciences, Shahroud, Iran

7: School of Allied Medicine, Shahroud University School of Medical Sciences, Shahroud, Iran.

Correspond Author: Dr. Moslem Jafarisani, PhD of Clinical Biochemistry, School of Allied Medicine, Shahroud University School of Medical Sciences, Shahroud, Iran. Tell: +989155331887. Email: moslem.jafarisani@shmu.ac.ir 


\begin{abstract}
Background: Coronavirus pandemic has affected a large population worldwide. Currently, the standard care for individuals who are exposed is supportive care, symptomatic management, and isolation. The aim of our study was to evaluate effects of combined use of ethanol and DMSO as a nasal spray in preventing COVID-19.
\end{abstract}

Methods: We conducted a randomized controlled trial on volunteer healthcare workers of medical centers that were at the forefront of the fight against COVID19 in Shahroud, Iran. Two hundred and thirty-two participants were randomly assigned to intervention and control groups to receive DMSO/ethanol or routine care, respectively. The subjects were followed for 4 weeks to determine the incidence of COVID-19 infection in each group based on the RT-qPCR test. Finally, absolute risk difference and relative risk were calculated to evaluate the effect of DMSO in prevent COVID-19.

Results: The results showed that the incidence of COVID-19 in the control group and intervention group were 0.07 and 0.008 , respectively. The relative risk (RR) was $0.12(0.9-0.02)$ according to the incidence rate in the two groups.

Conclusion: combined application of DMSO and ethanol in healthcare providers can considerably prevent COVID-19.

Key words: COVID-19, Ethanol, DMSO, healthcare workers, RCT 
medRxiv preprint doi: https://doi.org/10.1101/2021.07.06.21259749; this version posted July 18, 2021. The copyright holder for this preprint

(which was not certified by peer review) is the author/funder, who has granted medRxiv a license to display the preprint in perpetuity.

It is made available under a CC-BY-NC 4.0 International license.

\section{Introduction:}

SARS-COV-2 is a positive-sense single-stranded RNA virus that causes COVID19. The coronavirus has affected a large population worldwide since the beginning of the pandemic in December 2019 in Wuhan, China. It has resulted in 155 million infections and 3.24 million death until May 6, 2021(1).

The virus has become a major health challenge to human, health care systems, and global economy $(2,3)$ for several reasons including (i) the rate, extent, and variety of transmission routes,(ii) the confusing variety of clinical symptoms, and (iii) the unfamiliar and unusual response of the human immune system to COVID-19. Therefore, the current pandemic has become one of the top priorities of all countries (4).

Due to the absence of the virus in bloodstream available antiviral drugs are not effective $(5,6)$. The production of a potent and stable vaccine against the virus is also questionable because of the instability of the virus genome, which leads to continuous changes in the protein structures of the virus (7-9). In addition, due to technology of production and storage requirements, they are very expensive and their availability is limited especially in developing countries. Therefore, in order to control the disease, preventive methods that are available in all geographical areas are required $(10,11)$.

SARS-CoV-2 tends to infect the nasal and pharyngeal cavities (upper respiratory tract) for colonization and proliferation for the first few days after entering the body. Therefore, the delivery of effective therapeutics for the prevention and treatment of the disease can be done easily (7-9). The virus only owns the genome and proteins synthesized in the host cell and obtains its phospholipid bilayer from the host cell membrane. Since the virus envelope contains only phospholipids and has no cholesterol, it is very unstable and is a suitable target to destroy the viral particles (12). Thus, hygroscopic and lipolytic agents seem to be able to disrupt the SARS-CoV-2 envelope $(13,14)$. Such compounds denature proteins structure by absorbing excess water and include (i) Organic solvents such as ethanol, ether, chloroform and DMSO (ii) Ionic and non-ionic detergents such as Tween 80, Triton X100 and SDS (15). 
medRxiv preprint doi: https://doi.org/10.1101/2021.07.06.21259749; this version posted July 18, 2021. The copyright holder for this preprint

SARS-CoV-2 spike protein plays a crucial role in binding to the angiotensin receptor and entering the lung cell, so unfolding the spike; disrupts this process and the viruses particles cannot continue their life cycle $(16,17)$. Studies show that ethanol and DMSO have the least toxicity human cells and rats $(18,19)$. Therefore, using a solution containing 3\% dimethyl sulfoxide (DMSO) and 20\% ethanol as an intranasal inhalation spray may destroy the viruses' structure, break the virus transmission chain, and reduce the pathogenicity of the virus.

The present study aims to evaluate effects of a solution of $20 \%$ ethanol, $3 \%$ DMSO, and $0.1 \%$ menthol as a nasal spray in preventing from SARS-CoV-2 infection.

\section{Methods}

A single-center, two-armed 1:1, randomized controlled trial design was conducted to examine effects of DMSO-ethanol nasal spray in the prevention of COVID-19. The study population was healthy personnel of medical centers, who had no history of COVID-19 disease, in Shahroud. Healthy personnel of medical centers in Shahroud (northeast of Iran), who had no history of infection with COVID-19 and volunteered to participate in this trial study, was invited. Two hundred and thirtytwo participants were recruited using the convenience sampling method during 2020 from a general referral teaching hospital in Shahroud, Iran (Figure 1). At the beginning of the study, serum $\operatorname{IgG}$ and $\operatorname{IgM}$ antibodies were tested using a rapid test kit to confirm that volunteers were not infected with COVID-19. The inclusion criteria included all the healthy personnel of the medical centers that were volunteers to participate in the study and those who had a history of seizures or mental illness, allergy to any ingredient included in the spray, acute febrile disease on the day of enrolment, they had received any blood products in the past 4 months; and being unable to comply with the study schedule excluded from the study. The process of conducting the study, the possible benefits and harms of the intervention, the right to withdraw from the study at the desired time, and the 
medRxiv preprint doi: https://doi.org/10.1101/2021.07.06.21259749; this version posted July 18, 2021. The copyright holder for this preprint

confidentiality of the information obtained were explained to eligible individuals and informed consent was obtained from them. The random allocation sequence was created online (www.sealedenvelope.com/simple-randomiser/v1/lists) to randomly determine the composition of blocks (size of each block 4). Then, the participants in the study were randomly allocated to two groups receiving routine care + DMSO combination spray with ethanol and routine care alone (Figure 1). For concealment purposes, the random allocation order was placed in closed opaque envelopes. Due to the nature of the study, it was not possible to blind the participants but the data collector, and the data analyzer were blinded. Enrollment and allocation of participants to study groups was done by a nurse who was trained in this field. Then, a $20 \mathrm{cc}$ spray containing a combination of DMSO and ethanol was given to the individual assigned to the intervention group, and how to use it was taught by the nurse. Individuals assigned to the intervention group were advised to spray a puff of DMSO spray into each nostril every 8 hours for four weeks in addition to routine daily care. It was recommended for the control group to continue daily routine care (Figure 1). The outcome study in the present study was COVID-19 infection. To determine the incidence of COVID-19 in each group, the subjects were followed for 4 weeks. During the follow-up period, RT-qPCR was performed to confirm or rule out the disease in individuals with clinical symptoms of COVID-19. Also, at the end of the fourth week, all participants in the study underwent RT-qPCR to investigate asymptomatic infections. Considering the power of $80 \%, \alpha=0.05$, effect size 0.1 , the minimum sample size was estimated to be 93 individuals in each group. The possibility of participant drops out was considered, and therefore the final sample size was determined to be 116 individuals in each group.

The research proposal was approved by the Medical Ethics Committee affiliated with Shahroud University of Medical Sciences (decree code: 
medRxiv preprint doi: https://doi.org/10.1101/2021.07.06.21259749; this version posted July 18, 2021. The copyright holder for this preprint (which was not certified by peer review) is the author/funder, who has granted medRxiv a license to display the preprint in perpetuity.

It is made available under a CC-BY-NC 4.0 International license .

IR.SHMU.REC.1399.091). The research protocol was registered at the IRCT website under the number of IRCT20200727048217N. We obtained written informed consent from all the participants in 2 copies. In this study, in order to evaluate the effect of using the combination of DMSO with ethanol, absolute risk difference and relative risk were calculated. In calculating the absolute risk difference, the group that received routine care was considered as the exposed group.

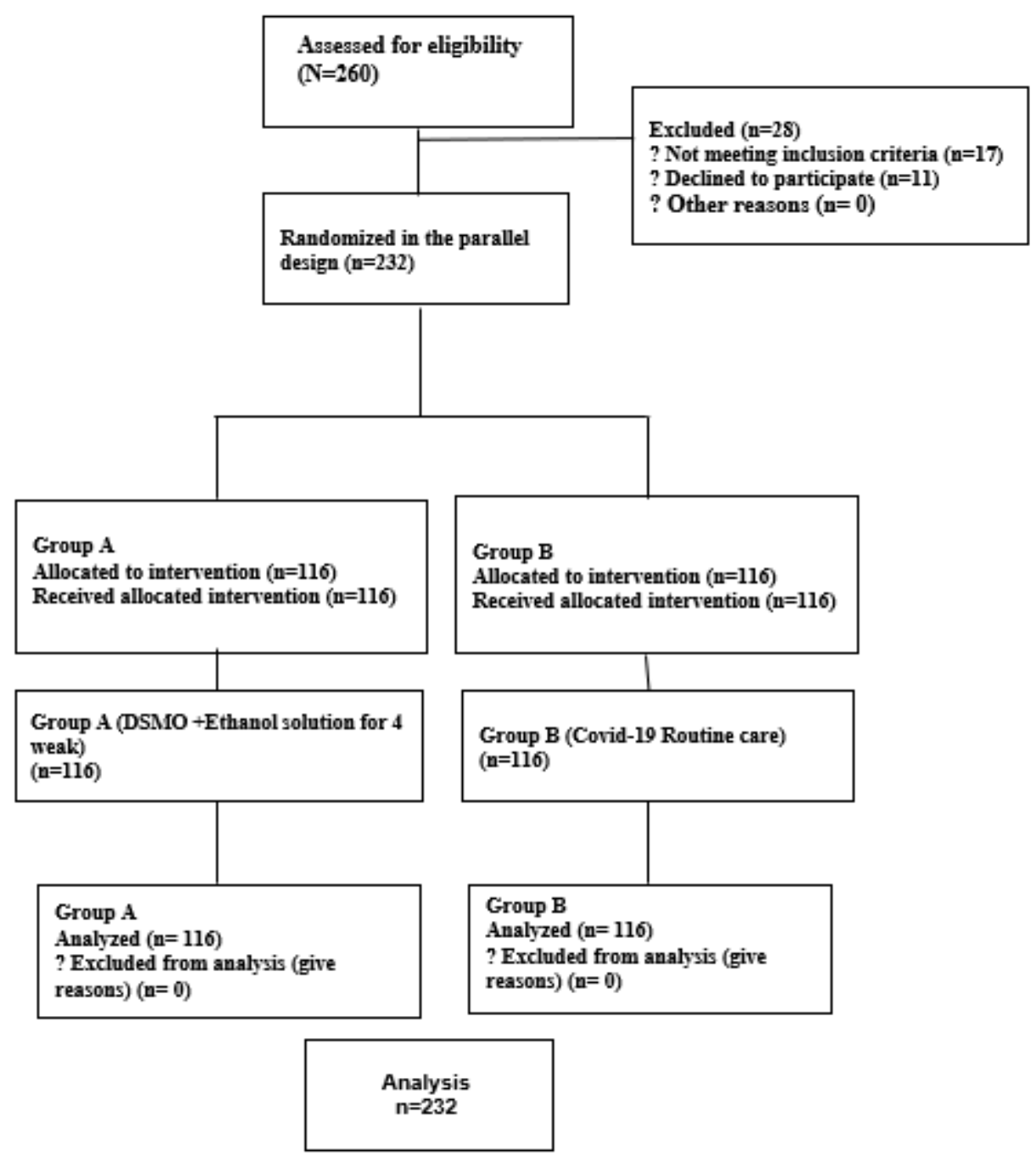

Figure 1. The process of the study according to the CONSORT flow diagram.

STATA version 16 was used for the data analysis. Descriptive statistics including mean and standard deviation for quantitative variables and frequency and 
medRxiv preprint doi: https://doi.org/10.1101/2021.07.06.21259749; this version posted July 18, 2021. The copyright holder for this preprint (which was not certified by peer review) is the author/funder, who has granted medRxiv a license to display the preprint in perpetuity. It is made available under a CC-BY-NC 4.0 International license .

percentage for qualitative variables were applied to describe these variables. Statistical tests were two tailed and p-value $<0.05$ was considered as the level of significance.

\section{Results}

The mean and standard deviation of the participant's age in this study was 37.18 \pm 8.69 . Most of the participants 62.3 percent were women and the rest 37.7 percent men. Other characteristics of the participants are listed in Table 1.

Table 1. The characteristics of study participants

$\begin{array}{llll}\text { Variable } & \text { Intervention group } & \text { Control group } & \text { P-value } \\ \text { Age } & 38.28 \pm 9.96 & 36.01 \pm 6.96 & 0.16 \\ \text { Work experience } & 3.82 \pm 1.66 & 4.03 \pm 1.67 & 0.34 \\ \text { sex } & & & \\ \quad \text { Men } & 48(40.7) & 40(34.5) & 0.32 \\ \quad \text { women } & 68(59.3) & 76(65.5) & \\ \text { Residence } & & & 0.54 \\ \quad \text { Rural } & 111(96.4) & 5(3.6) & \\ \text { Urban } & 113(98.0) & 3(2.0) & \end{array}$

Based on the results of PCR, out of 116 recipients of DMSO-ethanol combination, 1(0.8\%) developed COVID-19 during the follow-up period, but out of 116 people assigned to the control group, $8(6.8 \%)$ were diagnosed with COVID-19. The incidence of COVID-19 in the control group and intervention group were 0.07 and 0.008, respectively. According to the incidence rate in the two groups, the relative risk was $\mathrm{RR}=0.12(0.9-0.02)$. This means that the combination of DMSO with ethanol reduces the risk of COVID-19 by up to $88 \%$ (Attributable Fraction Exposer) (Table 2). 
medRxiv preprint doi: https://doi.org/10.1101/2021.07.06.21259749; this version posted July 18, 2021. The copyright holder for this preprint (which was not certified by peer review) is the author/funder, who has granted medRxiv a license to display the preprint in perpetuity.

It is made available under a CC-BY-NC 4.0 International license.

Table 2. Outcomes of DMSO + Ethanol Solution therapy against COVID-19

\begin{tabular}{|c|c|c|c|c|c|c|}
\hline \multirow[b]{2}{*}{ Intervention } & \multicolumn{2}{|c|}{ Outcome n (\%) } & \multirow[b]{2}{*}{ Risk } & \multirow[b]{2}{*}{ Risk ratio } & \multirow{2}{*}{$\begin{array}{l}\text { Absolut risk } \\
\text { difference }\end{array}$} & \multirow{2}{*}{$\begin{array}{l}\text { Attributable } \\
\text { fraction } \\
\text { exposer }\end{array}$} \\
\hline & $\begin{array}{l}\text { Confirmed } \\
\text { COVID-19 }\end{array}$ & $\begin{array}{l}\text { Non confirmed } \\
\text { COVID-19 }\end{array}$ & & & & \\
\hline $\begin{array}{l}\text { DMSO + Ethanol } \\
\text { solution }\end{array}$ & $1(0.88)$ & $115(99.12)$ & 0.008 & \multirow{2}{*}{$\begin{array}{c}0.12(0.02- \\
0.97)\end{array}$} & \multirow[t]{2}{*}{$\begin{array}{c}0.06(0.01- \\
0.11)\end{array}$} & \multirow[t]{2}{*}{$\begin{array}{c}0.87(0.06 \\
0.79)\end{array}$} \\
\hline Routine care & $8(2.89)$ & 108(93.1) & 0.07 & & & \\
\hline
\end{tabular}

\section{Discussion}

The present study showed that the use of DMSO in combination with ethanol significantly reduced the risk of COVID-19. According to the results, the risk of COVID-19 was about 8-fold higher in those who used routine care than in those who used DMSO spray. Due to the structure of the virus and the mechanism of action of the combination of DMSO with ethanol, the reduction in the risk of COVID-19 in people taking this spray can be justified.

Most viruses including coronavirus species have an envelope, wherein all functionally important virus surface proteins are implanted and secured from dismantling or falling off the virus coat. The virus lipid bilayer is completely derived from host cells, and the virus's genome has nothing to do with its generation. Therefore, it will not be affected by the extreme mutability of the virus. The physicochemical characteristics of the viral lipid envelope not only help the virus to maintain its spherical structure, but also play a pivotal role as a concrete foundation for the viral surface proteins (20). It is of extreme importance to know that the lipid envelopes of these virus species are highly sensitive to desiccation imposed by hygroscopic chemical agents and lipid-solving substances. Thus, it is utterly simple to conceptualize that even trivial and hardly noticeable changes in the lipid membrane ultra-structural properties could deeply affect the virus infectivity and virulence (21). Considering that most viruses including coronavirus species are wrapped up by an envelope, which is completely derived from the hosting cell, and the virus's genome has nothing to do with its generation (20). 
medRxiv preprint doi: https://doi.org/10.1101/2021.07.06.21259749; this version posted July 18, 2021. The copyright holder for this preprint

Therefore, induction of noticeable dryness at the surface of the coronavirus envelope and the nasal cavity epithelial cell membrane as well may cause the process of virus-epithelial cell attachment less.

DMSO is an aprotic polarity solvent that effectively solubilizes a wide variety of organic and inorganic chemicals including lipids with an unquestionable safety profile even at high molar concentrations. It looks as if even low concentrations of DMSO are yet of drastic effect on inducing dehydration and desiccation of lipid membranes. DMSO desiccates and weakens the lipid bio-membrane of cells and microorganisms (22-26). In a comprehensive and professionally designed biochemical study regarding the DMSO inducing dehydration near lipid membrane surfaces C-Y. Cheng concludes that DMSO "sprayed" on lipid surfaces even at low molar concentrations induces profound dehydration of lipid membranes, leading to marked physicochemical changes. He states that the physicochemical effects of DMSO on lipid surfaces are complex and significant at a broad range of DMSO concentrations (27). DMSO is known to directly interact with phospholipid bilayers as well. Molecular dynamics simulations of DMSO- dipalmitoyl phosphatidylcholine systems demonstrate that DMSO modulates the mechanical properties of lipid bilayers, reducing the area compressibility, thickness, solidarity, stability, and bending moduli. These cumulative effects make the lipid layer loose and floppy (28-34). DMSO also causes significant changes on the phospholipid bilayer of cultured skin fibroblast cells and disturbs the quality of the membrane lipid matrix. Numerous biophysical studies clearly demonstrate that the DMSO can induce phospholipid bilayer thinning and create pores through membrane lipid structures. These findings lend support and shed light on the facts behind the antimicrobial and antiviral effects of DMSO. It has been shown that topical DMSO blocks the transcription-replication process of the lipid enveloped, dsDNA 
medRxiv preprint doi: https://doi.org/10.1101/2021.07.06.21259749; this version posted July 18, 2021. The copyright holder for this preprint

containing herpes simplex virus, introducing itself as a direct antiviral agent (35). DMSO has been shown to potentiate the antiviral effects of all disinfectants. DMSO is also among the low toxicity solvents exerting strong free radical scavenger activity. An impressive research work by L. Costa reveals that DMSO decreases cell proliferation and TNF-a, IFNs, and IL-2 production in cultures of peripheral blood lymphocytes. This study signifies the strong anti-inflammatory effects and cytokines storm-preventing capabilities of DMSO (36).

Also, a CDC guideline [2008] regarding chemical disinfectants states that ethanol has generally been underrated as a potent antiviral agent inactivating and disinfecting all "enveloped lipophilic viruses". The widely accepted explanation for the antiviral action of ethyl alcohol is the denaturation of viral proteins and phospholipid bilayer envelope. In a recent study published by G. Kampf, $80 \%$ ethanol was highly effective at killing all 21 tested enveloped viruses within only 30 seconds (37). Another report reveals that ethanol disinfects the lipid-coated viruses instantly in less than 10 seconds. The desiccation and partial denaturation of the virus lipid coat would simply loosen the embedded proteins across the virus envelope. Therefore, it is a reasonable expectation that even low concentrations of a desiccating substance (DMSO) in conjunction with a powerful lipid solvent (ethanol) might execute the desired impact on enveloped viruses. Kampf specifies that the powerful antiviral effects of ethanol were not as remarkable in virus species lacking lipid bilayer coat. It obviously indicates that the primary target for antiviral effects of ethanol is the virus lipid coat (37).

we know that viruses are obligatory and obsessed inhabitant of nasal cavity mucosa, throat, pharynx, and later in its pathogenesis, the lower respiratory tract epithelial cells, alveolar pneumocytes, and capillary endothelial cells (38). We also know that SARS-COV-2 has no noticeable desire to present high viral load viremia 
medRxiv preprint doi: https://doi.org/10.1101/2021.07.06.21259749; this version posted July 18, 2021. The copyright holder for this preprint

(39) and uses angiotensin-converting enzyme-2 (ACE-2) as the major binding site to enter the cells, and we know that the upper and lower respiratory tract harbors the highest concentrations of this protein. Thus, the SARS-CoV-2 must be regarded as a restricted inhabitant of our respiratory tract. Based on these practical reasons, we can constantly intrude and continuously disturb the coronavirus replication milieu in nasal cavities and oropharyngeal area via a nasal spray composed of DMSO and ethanol and causing total turmoil in the breeding and replicating virus herd inside the nasopharynx and throat.

\section{Strengths and limitations}

We acknowledge that this trial has some limitations. First, this phase 3 trial started before the full analysis of the data from the phase 1 and 2 study. Second, it was not possible to blind the study groups. Third, the total dose of iodine absorbed by the suggested regimen is not known exactly. The main strength of this study is, first, DMSO and ethanol have very few contraindications as a mouthwash or nasal spray. second, administration is cheap, simple and rapid. Third, it is readily available in healthcare worldwide. Forth, sensitization is extremely rare.

\section{Conclusion}

The results of this study showed that the use of combination DMSO and ethanol in healthcare providers can considerably prevent COVID-19.

\section{Recommendation for practice}

This study highlighted that the use of DMSO and ethanol is an effective way for the prevent of COVID-19 in medical centers. As a result, the findings of this study if replicated by other studies can be used by healthcare providers, such as physicians, and nurses to reduce risk of COVID-19.

\section{Funding source}


medRxiv preprint doi: https://doi.org/10.1101/2021.07.06.21259749; this version posted July 18, 2021. The copyright holder for this preprint (which was not certified by peer review) is the author/funder, who has granted medRxiv a license to display the preprint in perpetuity.

It is made available under a CC-BY-NC 4.0 International license .

This work was supported by Shahroud University of Medical Sciences

Declaration of competing interests

The authors declare that there is no conflict of interest

\section{Acknowledgments}

This study was supported by grant No 9956 from Shahroud University of Medical Sciences. 
medRxiv preprint doi: https://doi.org/10.1101/2021.07.06.21259749; this version posted July 18, 2021. The copyright holder for this preprint (which was not certified by peer review) is the author/funder, who has granted medRxiv a license to display the preprint in perpetuity. It is made available under a CC-BY-NC 4.0 International license .

\section{References}

1. COVID-19 Dashboard by the Center for Systems Science and Engineering (CSSE) at Johns Hopkins University (JHU)". ArcGIS. Johns Hopkins University. 2021

2. Tandon R. COVID-19 and mental health: preserving humanity, maintaining sanity, and promoting health. Asian journal of psychiatry. 2020.

3. Prideaux B, Thompson M, Pabel A. Lessons from COVID-19 can prepare global tourism for the economic transformation needed to combat climate change. Tourism Geographies. 2020;22(3):667-78.

4. Mason RJ. Pathogenesis of COVID-19 from a cell biology perspective. European Respiratory Journal. 2020;55(4):2000607.

5. Cevik M, Kuppalli K, Kindrachuk J, Peiris M. Virology, transmission, and pathogenesis of SARSCoV-2. BMJ. 2020;371:m3862.

6. Yuki K, Fujiogi M, Koutsogiannaki S. COVID-19 pathophysiology: A review. Clin Immunol. 2020;215:108427-.

7. Tinari S. The EMA COVID-19 data leak, and what it tells us about mRNA instability. bmj. 2021;372.

8. Analytica O. Instability threatens Ecuador's vaccine roll-out. Emerald Expert Briefings. 2021(oxan-es).

9. Forni G, Mantovani A. COVID-19 vaccines: where we stand and challenges ahead. Cell Death \& Differentiation. 2021;28(2):626-39.

10. Mills MC, Salisbury D. The challenges of distributing COVID-19 vaccinations. EClinicalMedicine. 2021;31.

11. Wouters OJ, Shadlen KC, Salcher-Konrad M, Pollard AJ, Larson HJ, Teerawattananon Y, et al. Challenges in ensuring global access to COVID-19 vaccines: production, affordability, allocation, and deployment. The Lancet. 2021.

12. Trougakos IP, Stamatelopoulos K, Terpos E, Tsitsilonis OE, Aivalioti E, Paraskevis D, et al. Insights to SARS-CoV-2 life cycle, pathophysiology, and rationalized treatments that target COVID-19 clinical complications. Journal of Biomedical Science. 2021;28(1):9.

13. Scheller C, Krebs F, Minkner R, Astner I, Gil-Moles M, Wätzig H. Physicochemical properties of SARS-CoV-2 for drug targeting, virus inactivation and attenuation, vaccine formulation and quality control. Electrophoresis. 2020;41(13-14):1137-51.

14. Mitaku S, Ikuta K, Itoh H, Kataoka R, Naka M, Yamada $M$, et al. Denaturation of bacteriorhodopsin by organic solvents. Biophysical chemistry. 1988;30(1):69-79.

15. Tumenas S, Ragaliauskas T, Penkauskas T, Valanciute A, Ambrulevicius F, Valincius G. Solvent effects on composition and structure of thiolipid molecular anchors for tethering phospholipid bilayers. Applied Surface Science. 2020;509:145268.

16. Guo C, Steinberg LK, Henderson JP, Gross ML. Organic Solvents for Enhanced Proteolysis of Stable Proteins for Hydrogen-Deuterium Exchange Mass Spectrometry. Analytical Chemistry. 2020;92(17):11553-7.

17. Magsumov T, Ziying L, Sedov I. Comparative study of the protein denaturing ability of different organic cosolvents. International Journal of Biological Macromolecules. 2020;160:880-8.

18. Rothan HA, Stone S, Natekar J, Kumari P, Arora K, Kumar M. The FDA-approved gold drug auranofin inhibits novel coronavirus (SARS-COV-2) replication and attenuates inflammation in human cells. Virology. 2020;547:7-11.

19. Rabow Z, Morningstar T, Showalter M, Heil H, Thongphanh K, Fan S, et al. Exposure to DMSO during infancy alters neurochemistry, social interactions, and brain morphology in long-evans rats. Brain and Behavior.n/a(n/a):e02146. 
medRxiv preprint doi: https://doi.org/10.1101/2021.07.06.21259749; this version posted July 18, 2021. The copyright holder for this preprint (which was not certified by peer review) is the author/funder, who has granted medRxiv a license to display the preprint in perpetuity. It is made available under a CC-BY-NC 4.0 International license .

20. De Haan CA, Kuo L, Masters PS, Vennema H, Rottier PJ. Coronavirus particle assembly: primary structure requirements of the membrane protein. Journal of virology. 1998;72(8):6838-50.

21. Basso LG, Vicente EF, Crusca Jr E, Cilli EM, Costa-Filho AJ. SARS-CoV fusion peptides induce membrane surface ordering and curvature. Scientific reports. 2016;6(1):1-19.

22. Capriotti K, Capriotti JA. Dimethyl sulfoxide: history, chemistry, and clinical utility in dermatology. The Journal of clinical and aesthetic dermatology. 2012;5(9):24.

23. Marren K. Dimethyl sulfoxide: an effective penetration enhancer for topical administration of NSAIDs. The Physician and sportsmedicine. 2011;39(3):75-82.

24. Rössberger J, Fall M, Peeker R. Critical appraisal of dimethyl sulfoxide treatment for interstitial cystitis discomfort, side-effects and treatment outcome. Scandinavian journal of urology and nephrology. 2005;39(1):73-7.

25. Hoang BX, Tran DM, Tran HQ, Nguyen PT, Pham TD, Dang HV, et al. Dimethyl sulfoxide and sodium bicarbonate in the treatment of refractory cancer pain. Journal of pain \& palliative care pharmacotherapy. 2011;25(1):19-24.

26. Fishman E, Jenkins Jr L, Coon R, Jones R. Effects of acute and repeated inhalation of dimethyl sulfoxide in rats. Toxicology and Applied Pharmacology. 1969;15(1):74-82.

27. Cheng $\mathrm{C}-\mathrm{Y}$, Song J, Pas J, Meijer LH, Han S. DMSO induces dehydration near lipid membrane surfaces. Biophysical journal. 2015;109(2):330-9.

28. Notman R, den Otter WK, Noro MG, Briels WJ, Anwar J. The permeability enhancing mechanism of DMSO in ceramide bilayers simulated by molecular dynamics. Biophysical journal. 2007;93(6):205668.

29. de Menorval M-A, Mir LM, Fernández ML, Reigada R. Effects of dimethyl sulfoxide in cholesterol-containing lipid membranes: a comparative study of experiments in silico and with cells. PloS one. $2012 ; 7(7): e 41733$.

30. Singh $M$, McKenzie $K, M a X$. Effect of dimethyl sulfoxide on in vitro proliferation of skin fibroblast cells. Journal of Biotech Research. 2017;8:78.

31. Gurtovenko AA, Anwar J. Modulating the structure and properties of cell membranes: the molecular mechanism of action of dimethyl sulfoxide. The journal of physical chemistry B. 2007;111(35):10453-60.

32. Chang HH, Dea PK. Insights into the dynamics of DMSO in phosphatidylcholine bilayers. Biophysical chemistry. 2001;94(1-2):33-40.

33. Malajczuk CJ, Hughes ZE, Mancera RL. Molecular dynamics simulations of the interactions of DMSO, mono-and polyhydroxylated cryosolvents with a hydrated phospholipid bilayer. Biochimica et Biophysica Acta (BBA)-Biomembranes. 2013;1828(9):2041-55.

34. Notman R, Noro M, O'Malley B, Anwar J. Molecular basis for dimethylsulfoxide (DMSO) action on lipid membranes. Journal of the American Chemical Society. 2006;128(43):13982-3.

35. Aguilar J, Roy D, Ghazal P, Wagner E. Dimethyl sulfoxide blocks herpes simplex virus-1 productive infection in vitro acting at different stages with positive cooperativity. Application of microarray analysis. BMC infectious diseases. 2002;2(1):1-10.

36. de Abreu Costa L, Henrique Fernandes Ottoni M, Dos Santos MG, Meireles AB, Gomes de Almeida $\mathrm{V}$, de Fátima Pereira W, et al. Dimethyl sulfoxide (DMSO) decreases cell proliferation and TNF$\alpha$, IFN- $\gamma$, and IL-2 cytokines production in cultures of peripheral blood lymphocytes. Molecules. 2017;22(11):1789.

37. Kampf G. Efficacy of ethanol against viruses in hand disinfection. Journal of Hospital Infection. 2018;98(4):331-8.

38. Jin Y, Yang H, Ji W, Wu W, Chen S, Zhang W, et al. Virology, epidemiology, pathogenesis, and control of COVID-19. Viruses. 2020;12(4):372. 
medRxiv preprint doi: https://doi.org/10.1101/2021.07.06.21259749; this version posted July 18, 2021. The copyright holder for this preprint (which was not certified by peer review) is the author/funder, who has granted medRxiv a license to display the preprint in perpetuity.

It is made available under a CC-BY-NC 4.0 International license.

39. Chang L, Yan Y, Wang L. Coronavirus disease 2019: coronaviruses and blood safety. Transfusion medicine reviews. 2020;34(2):75-80. 